\title{
Influence of Partially Purify Enzyme in Experimental Cheddar Cheese Production
}

\author{
M. Pagthinathan
}

\begin{abstract}
Calf rennet is the main enzyme component has been widely used as a milk clotting enzyme for cheese making. The high price of traditional rennets and ethical consideration associated with their use promoted the new rennet substitute. The cheeses were studied to determined difference chemical, biochemical and sensory characteristics throughout of 2 months of ripening. The cheese yield produced from commercial enzyme was $(p<0.05)$ higher than cheese produce from kesinai enzymes. Both cheese samples were compositionally alike except for moisture, protein contents and pH. In both cheese moisture contents declined $(p<0.05)$ with ripening period while $\mathrm{pH}$ was increased with ripening time. Total nitrogen (TN), non protein nitrogen (NPN) and non casein nitrogen $(\mathrm{NCN})$ were $(\mathrm{p}<0.05)$ higher in whey of cheese made with kesinai enzyme than cheese made with commercial enzyme. The amount of NPN and NCN found in cheese made with kesinai enzyme was $(\mathbf{p}<0.001)$ higher than in cheese made with commercial enzyme. NPN and NCN values were increased $(p<0.001)$ throughout the ripening period in both cheeses. Cheese made with commercial enzyme exhibited slightly higher level of free amino acids than cheese made with kesinai enzyme. But free fatty acids compositions have shown similar changes in both types of cheese thought the ripened time. Textual characteristics such as hardness, gumminess and chewiness increased in both types of cheese during early stage of ripening and decrease gradually at end of ripening whereas springiness, adhesiveness and cohesiveness were showed similar changes in both cheeses during the ripened period. The principal component analysis (PCA) of electronic nose sensor data has been studied using "Z"nose. The results indicated that, the presence of 7 volatile (aroma) common compounds in both cheeses. PCA analysis was performed to discriminate the cheeses with their ripening time.
\end{abstract}

Index Terms-Biochemical, Cheese, Enzyme, Kesinai Ripening, Texture.

\section{INTRODUCTION}

Calf rennet is the main enzyme component that is widely used as a milk-clotting enzyme for cheese-making [1]. The high price of traditional calf-rennets, demand and ethical considerations related with their use has promoted the search for new rennet substitutes [2-4]. Rrecombinant chymosin would be interesting considering its availability and low cost due to the use cheap substrates for large scale fermentation with highly pure chymosin [4-5]. Apart from that, many other proteases are capable to coagulating milk, which have been derived from variety of microbial, animal

Published on April 02, 2020.

Mylvaganam Pagthinathan as a Senior Lecture in Animal Science,

Faculty of Agriculture, Eastern University Sri Lanka, Sri Lanka.

(e-mail: pagthinathanm@esn.ac.lk) and plant sources [3]. Plant coagulants have been used for any centuries in the production of cheese [6]. The extracts of Cynara species, C. cardunculus C. humilis, and $C$. scolymus, have been claimed to be as effective as rennet [7]. However, plant coagulants have excessive proteolytic character, leading to lower cheese yield and produces bitter flavour with texture defect in the final cheese [6]-[8].

Previous studies have shown that kesinai protease could be used as an alternative substitute for milk-coagulation [911]. The enzyme from kesinai exhibited the highest milkclotting activity at $70{ }^{\circ} \mathrm{C}$ and $\mathrm{pH} 6$ [12], with comparable proteolytic activity with commercial rennet (Maxiren). The extract of $C$. cardunculus flowers containing proteases has been used for the manufacture of sheep milk cheese in several areas of Portugal and Spain. Similarly, Solanum dubium and Calotropis procera were producing traditional whitish soft cheese [5]-[13]. They also have a strong proteolytic character that leads to the extensive break down of casein, producing soft buttery texture with slightly piquant and creamy flavour [14]. However, there is very little information about producing cheese using kesinai protease. Hence, the objective of this present study was to investigate the application of kesinai (S. asper) protease on the physiochemical properties of cheese made with cow's milk, and comparison was made with cheese produced using a commercial rennet.

\section{MATERIALS AND METHODS}

\section{A. Cheese Making Procedure}

Two batches with three replicate of Cheddar cheese were made from fresh cow's milk that had been pasteurized at $63{ }^{\circ} \mathrm{C}$ for $30 \mathrm{~min}$ and cooled to at $31{ }^{\circ} \mathrm{C}$. The starter culture (mesophilic homofermetative culture -F- DVS R603) was directly added into the vats according to the instructions of the manufacturer and mixed well for 4-5 min. After $60 \mathrm{~min}$, commercial enzyme enzyme (chymosin) (Hansen stick-Aspergillus niger var awamori) were obtained from Chr. Hansen, Denmark) was added for one batch according to the instructions of the manufacturer and the other batch kesinai protease was added at the rate of $0.29 \mathrm{~g}$ of protein/L of milk and mixed thoroughly for $1-2$ min. Subsequently, calcium chloride was added to the cheese milk at a level of $8.5 \mathrm{~g} \mathrm{CaCl} 2100 / \mathrm{L}$ of milk. After settled the coagulum, the coagulated milk were cut, cook and the time of cheddaring process allowed for acidity to develop in the curd the $\mathrm{pH}$ reduced about 5.4 according the procedure described by Fox et al. [15] and Punidadas et al. [16]. Then the cheeses were salted in brine $(2.5 \% \mathrm{NaCl})$. 
The curds were then pressed (at 40 psi or $12 \mathrm{~h}$ ) in $10 \mathrm{~kg}$ stored for 2 months at $7-8^{\circ} \mathrm{C}$ in the vacuumed packed in Cryovac bags and cheese was taken 2, 15, 30, 45 and 60 days after manufacture.

\section{B. Determination of Chemical Components}

Moisture, fat, protein and ash were determined by AOAC [17] methods. Non-protein nitrogen (NPN) using $12 \%$ trichloroacetic acid and Non-casein nitrogen (NCP) as described by Barbano et al. [18] and Carmona et al. [19], respectively. The $\mathrm{pH}$ of cheese paste was measured according the method described by Patel et al. [20].

\section{High-Performance Liquid Chromatography (HPLC) Analysis of Free Amino Acids}

The free amino acid contents of cheese were analyzed by an HPLC (Jasco CO-2065 Plus) using gradient system with precolumn phenylisothiocyanate (PITC) derivatization. A $0.20 \mathrm{~g}$ of grinded cheese sample was mixed well with $15 \mathrm{~mL}$ of $6 \mathrm{~N} \mathrm{HCl}$ and the sample was flushed out nitrogen gas for $1 \mathrm{~min}$ and it was then incubated at $110{ }^{\circ} \mathrm{C}$ for 24 hours. After cooling the sample, internal standard (AABA) was added and samples were filtered with $0.2 \mu \mathrm{m}$ cellulose membrane. A $10 \mu \mathrm{L}$ of sample was transferred in a vial, and mixed with $10 \mu \mathrm{L}$ of standard and dried under vacuum during $30 \mathrm{~min}$. A $20 \mu \mathrm{L}$ of redrying solution was added into a sample and standard vial and dried under vacuum for 30 min. Then after the sample mixture incubated with 20 $\mu \mathrm{L}$ of derivation reagent for $20 \mathrm{~min}$ at room temperature and dried under vacuum for $30 \mathrm{~min}$. The derivative sample was used for mobile phase for HPLC as described by manufacturer. Samples $(40 \mu \mathrm{L})$ were injected into an HPLC system using a gradient system and operating was carried out temperature at $43{ }^{\circ} \mathrm{C}$. A C18 reversed-phase column (from Merck, Hibar ${ }^{R}$ RP -18 e 5U, 250-4.6 mm) was used, which was detected OD at $254 \mathrm{~nm}$ [21-22].

\section{Fatty Acid Analysis}

Fatty acid compounds in the cheese were determined as described by Alewijn et al. [23] and Alewijn et al. [24]. Fifteen gram of cheese was mixed with $4 \mathrm{~mL}$ of acetonitrile and was heated at $45^{\circ} \mathrm{C}$ for $10 \mathrm{~min}$. Then after centrifuged at $700 \mathrm{x} \mathrm{g}$ for $4 \mathrm{~min}$ at $4{ }^{\circ} \mathrm{C}$ and kept at $4{ }^{\circ} \mathrm{C}$ for $15 \mathrm{~min}$. The top layer of acetonitrile transfer in to $2 \mathrm{~mL}$ vial and kept at $20{ }^{\circ} \mathrm{C}$ for $30 \mathrm{~min}$ and $1 \mathrm{~mL}$ of the supernatant was transfer into a gas chromatography (GC) vial. Then adding of normal hexane $950 \mu \mathrm{L}$ to $50 \mu \mathrm{L}$ of cheese oil followed by $50 \mu \mathrm{L}$ of $1 \mathrm{M}$ sodium methoxide as described method by Cocks and van Rede [25]. The mixtures were vortex for 5 sec and allowed to settle for $5 \mathrm{~min}$. The top layer $(1 \mu \mathrm{L})$ was injected into a gas chromatograph (Model GC- Clarus 500 Perkin Elmer Incorporate, Massachusetts, USA) equipped with a flame ionization detector and a polar capillary column ELITE-5(30m x $0.25 \mathrm{~mm}$ ID x $0.25 \mu \mathrm{m}$, Perkin Elmer, USA) to obtain FA methyl ester peaks. The detector temperature was $240^{\circ} \mathrm{C}$ and column temperature was $130^{\circ} \mathrm{C}$ held for $0.5 \mathrm{~min}$ and increased at the rate of $10^{\circ} \mathrm{C} / \mathrm{min}$ to moulds. Finally the curd was $240^{\circ} \mathrm{C}$ and held for $5 \mathrm{~min}$ and a run time of $20.50 \mathrm{~min}$. Individual peaks of FA methyl esters were identified by comparing their retention times with those of standards.

\section{E. Texture Profile Analysis}

To determine the texture profile, cheese were cut into cylindrical sample of $20 \times 20 \times 20 \mathrm{~mm}$, placed in plastic cup, sealed (to prevent the dehydration), and store at $20^{\circ} \mathrm{C}$ for 1 hour prior to analysis. A 2 - bite compression test was performed using the Texture analyzer (model TA- XT2, Pulse Upgrade, Texture Analyzer - Stable Micro System, Gu71 YL/ UK) with a $5 \mathrm{~kg}$ load cell, TA P 75 probe. It was tested at $50 \%$ compression, with crosshead speed at 10 $\mathrm{mm} / \mathrm{min}$. Hardness, cohesiveness, gumminess, chewiness and adhesiveness were determined in the triplicate from the force - distance curve obtained from two- bite deformation curve of the texture profile as described by Awad et al. [26] and Awad [27].

\section{F. Electronic Nose Measurements}

According the method described by Gursoy et al. [28]. The aroma compounds of cheese were analyzed using an Ultrafast GC zNose 7100 analyser (Electronic Sensor Technology Co., Newbury Park, CA, USA). Before analysis, each cheese sample block kept at room temperature for at least an hour and $10 \mathrm{~g}$ each cheese sample from each cut placing into septa-sealed screw-cap bottle. Then the bottles were covered and heated at $60 \circ \mathrm{C}$ for $10 \mathrm{~min}$ using water bath. The sample's vapour was introduced into the electronic nose inlets (flow rate of helium gas was fixed at $3.5 \times 106 \mathrm{~m} 3 / \mathrm{min}$ ). The column and surface acoustic wave (SAW) quartz microbalance detector temperature were set at 40 to $200{ }^{\circ} \mathrm{C}$, and $60{ }^{\circ} \mathrm{C}$, respectively [29]. The aroma compound profile obtained from the electronic nose chromatogram and vaporprints ${ }^{\mathrm{TM}}$ (polar plots).

\section{G. Statistical Analysis}

Experimental data were subjected to analysis of variance (ANOVA) using the SAS Statistical Computer Package Version 9.1.3 (SAS Institute, Inc., USA, 2003). Duncan's multiple range tests was used to make the significant variation among means. Significance was defined at $\mathrm{P}<$ 0.05. Principal component analysis (PCA) was carried out on the electronic nose data to categorize the cheeses sample into different groups. Minitab, version 15.1 (Minitab Inc., State College, PA 16801, USA) software was used for these analyses.

\section{RESULTS AND DISCUSSIONS}

\section{A. Chemical Composition of Cheese}

At Day 1, the cheese yield produced from commercial enzyme was significantly higher $(p<0.05)$ than cheese 
produce from kesinai enzymes. The experimental cheddar cheeses were compositionally alike exception in their moisture, protein and $\mathrm{pH}$ of the cheese. The moisture contents was significantly $(p<0.05)$ higher in cheese made with kesinai enzyme than those from commercial enzyme, whereas $\mathrm{pH}$ and protein contents of cheese made from kesinai were significantly $(p<0.05)$ lower than that of cheese produced from commercial enzyme. The compositional attributes of cheeses were observed within normal range of cheddar cheese [20].

The biochemical changes in cheddar cheeses during ripening were shown in Table I. The moisture contents of cheese obtained with kesinai coagulant was higher than those produced by commercial enzyme throughout the ripening period, the moisture contents of cheeses were significantly $(\mathrm{p}<0.05)$ reduced with time of ripening. Patel et al. [20] and Pino et al. [30] were reported for moisture content was reduced with ripening time. Most of the moisture losses observed during the first 15 days of ripening, this may lead to the salting that took place during this period (Hofi et al. [31]. Initially $\mathrm{pH}$ in cheese made from kesinai protease was slightly lower than commercial enzyme. The $\mathrm{pH}$ cheese showed slightly reduction in early stage, after which a increased consistently throughout ripening. Galán et al. [14] was observed similar response for cheese produced from plant coagulant. It is reported that increasing $\mathrm{pH}$ during ripening of cheese attributed to the utilization of lactic acid from lactate, formation of non acidic decomposition products, and liberation of dissociated amino acid and alkaline products of protein decomposition [32]. The protein contents of cheese produced with kesinai coagulant was lower $(\mathrm{p}<0.05)$ than that produced by commercial enzyme. This suggests that kesinai protease was retained less protein in its cheese compare with commercial enzyme. The protein and fat contents were not significantly $(p>0.05)$ changed with ripening time in both cheeses. This result was agreed with finding from Cheddar cheese made by cow milk during its ripening process [33]. However, Galán et al. [14] has reported that protein and fat contents were increased with ripening time.

\section{B. Changes in the Nitrogen Components}

The amount of NPN found in cheese made with kesinai enzyme was significantly $(\mathrm{p}<0.001)$ higher than in cheese made with commercial enzyme (Table II). Although, non protein nitrogen value in cheeses made with kesinai enzyme and commercial enzyme were increased significantly $(p<0.001)$ throughout the ripening period. The NPN values obtained form cheese made with kesinai enzyme at day 1 and day 60 were $7.07 \mathrm{~g} / 100 \mathrm{~g}$ of TN and $11.97 \mathrm{~g} / 100 \mathrm{~g}$ of $\mathrm{TN}$, respectively. The values are similar to Galán et al. [14] reported for cheese made with Cynara carduncus extract at day land day 60 were $4.66 \mathrm{~g} / 100 \mathrm{~g}$ of TN and $11.16 \mathrm{~g} / 100 \mathrm{~g}$ of TN, respectively. These results were also agreed with cheese made using Cynara carduncus by Pino et al. [30]. According to Sousa and Malcata [34] and FernándezSalguero et al. [35] finding, it could be higher break down of caseins in cheeses made with kesinai enzyme led to more production of substrate (casein polypeptides), which leads to produce higher amounts of low molecular nitrogen (NPN) than those produced from commercial enzyme. Protein nitrogen was significantly $(p<0.001)$ higher in chesses made with commercial enzyme than those of kesinai enzyme throughout the ripening period. This result suggests that kesinai enzyme has less ability to retain the protein in cheese than commercial enzyme.

Throughout the ripening period, non casein nitrogen fractions $(\mathrm{NCN})$ was significantly $(\mathrm{p}<0.001)$ increased in cheeses made with kesinai enzyme and commercial. On the first day ripening, the $\mathrm{NCN}$ value for the cheese made using kesinai enzyme (13.29 g/100g of TN) was significantly $(p<0.001)$ higher than cheese obtained with commercial enzyme $(11.19 \mathrm{~g} / 100 \mathrm{~g}$ of $\mathrm{TN})$. At the end of the ripening period, the cheeses made with kesinai enzyme and commercial enzyme contained $18.66 \mathrm{~g} / 100 \mathrm{~g}$ of $\mathrm{TN}$ and $17.05 \mathrm{~g} / 100 \mathrm{~g}$ of TN respectively. Pino et al. [30] was reported that higher level of NCP appeared in cheese made by Cynara carduncus. The high level of NCN observed in the early stage of ripening of kesinai cheese, it is due to intense proteolytic action of the enzyme in the kesinai protease [36]. This high level of NCN during the early stage of ripening was reported for cheese made with extract of Cynara carduncus [14]-[30]-[37]. Casein nitrogen was significantly $(p<0.001)$ higher in chesses made with commercial enzyme than those of kesinai enzyme throughout the ripening period. Cheese protein is important in determine the suitability any protease for commercial cheese making [10].

\section{Individual Free Amino Acid}

Fig1 shown that when the ripening time increases, one could observe an increase in the concentration of amino acids. It also monitored that, the amount of total amino acids of the cheese made with kesinai enzyme at end of the ripening $(276.37 \mathrm{mg} / \mathrm{g}$ of cheese) was higher ( $>0.05$ ) than day1 ripening $(266.22 \mathrm{mg} / \mathrm{g}$ of cheese). Similarly cheese made from commercial enzyme the value at day 1 and end of the ripening were $278.14 \mathrm{mg} / \mathrm{g}$ of cheese and 290.73 $\mathrm{mg} / \mathrm{g}$ of cheese, respectively. Although, the amount of individual amino acids found in cheese made with kesinai enzyme lower than in cheese made with commercial enzyme, except phenylalanine no significant differences were found ( $>0.05$ ) between cheeses made with two types of coagulant during ripened time.

At ripening time, level of all individual amino acids were increasing, it could be the production of small peptide and amino acids probably by action of the starter and non-starter bacterial enzymes [38-39]. Moreover, many authors reported a positive relationship between the amino acids release in cheese and autolysis of the starter during cheese ripening process [40-42]. It noted that amino acids concentration in cheese only detected partly reflects the composition of casein [43]. Fox [44] reported the grater sources of amino acid produced from proteolytic activity of starter during early stage of ripening whereas later stage of 
ripening, non starter lacto bacillus bacteria contribute to

both the appearance and disappearance of amino acids [45]. 
TABLE I: CHANGES THROUGHOUT RIPENING IN COMPOSITION ATTRIBUTES OF CHEDDAR CHEESE MADE WITH KESINAI PROTEASE AND COMMERCIAL ENZYME

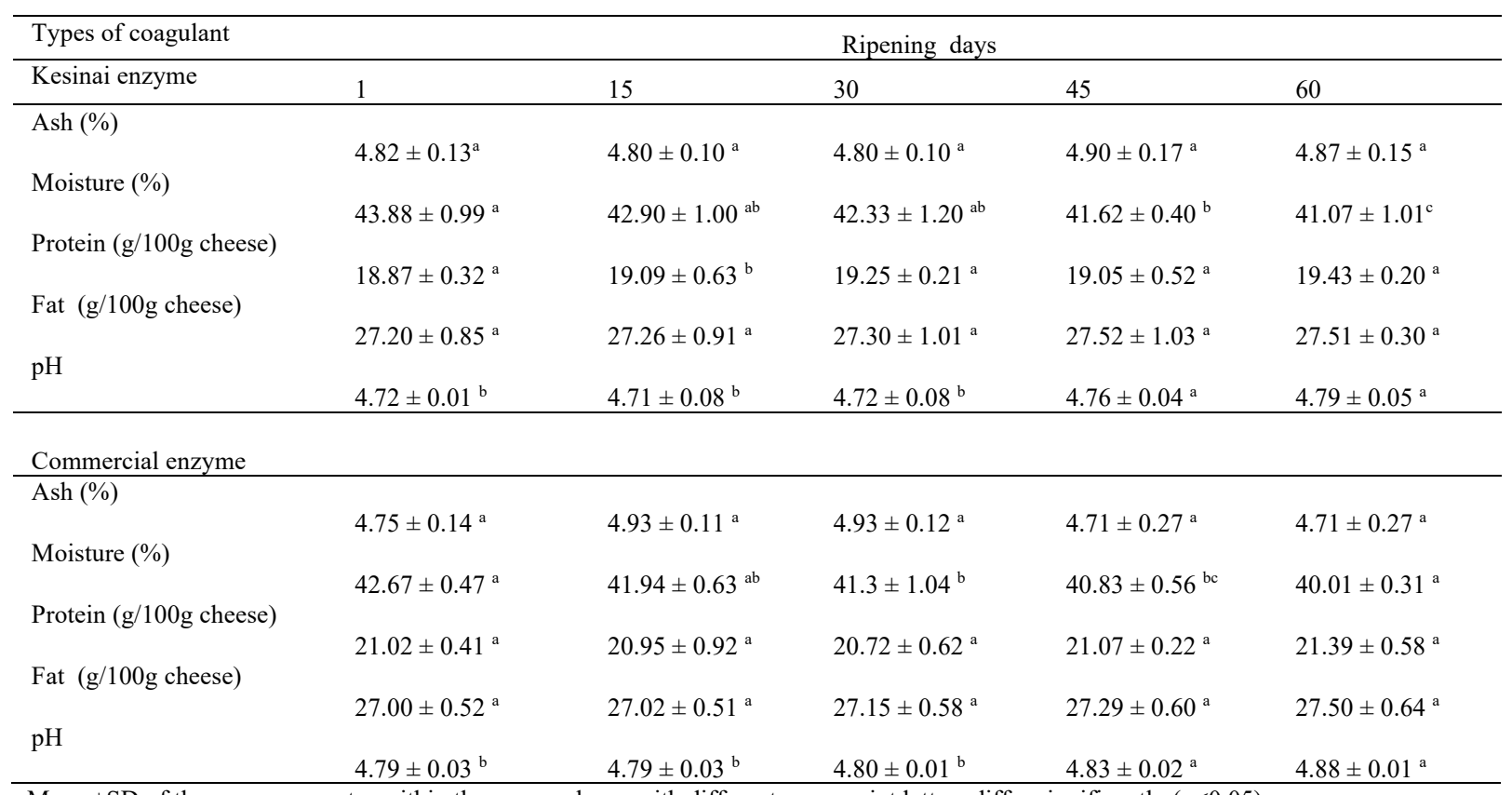

Mean \pm SD of the same parameter within the same column with different superscript letters differ significantly ( $<<0.05)$.

TABLE II: CHANGES THROUGHOUT RIPENING IN NITROGEN FRACTION (\%) OF CHEDDAR CHEESE MADE WITH KESINAI PROTEASE AND COMMERCIAL ENZYME

\begin{tabular}{|c|c|c|c|c|c|}
\hline Type of coagulant & \multicolumn{5}{|c|}{ Ripening days } \\
\hline Kesinai enzyme & 1 & 15 & 30 & 45 & 60 \\
\hline Non protein $\mathrm{N}$ & $7.07 \pm 0.16^{\mathrm{g}}$ & $8.85 \pm 0.79^{\mathrm{ed}}$ & $10.22 \pm 0.15^{\mathrm{cb}}$ & $10.72 \pm 0.22^{b}$ & $\begin{array}{l}11.97 \pm 0.89^{\mathrm{a}} \\
88.03 \pm 0.89^{\mathrm{h}}\end{array}$ \\
\hline Protein N & $92.93 \pm 0.16^{\mathrm{b}}$ & $91.14 \pm 0.79^{\text {ed }}$ & $89.72 \pm 0.15^{\mathrm{gf}}$ & $89.28 \pm 0.22^{g}$ & $1866+067^{\mathrm{a}}$ \\
\hline Non casein $\mathrm{N}$ & $13.29 \pm 0.15^{\mathrm{f}}$ & $14.85 \pm 0.20^{\mathrm{e}}$ & $16.38 \pm 1.05^{\mathrm{cd}}$ & $17.39 \pm 0.11^{b}$ & $10.00 \pm 0.01$ \\
\hline Casein $\mathrm{N}$ & $86.71 \pm 0.15^{\mathrm{b}}$ & $85.14 \pm 0.20^{\mathrm{c}}$ & $83.62 \pm 1.05^{\mathrm{de}}$ & $82.61 \pm 0.11^{\mathrm{f}}$ & $81.34 \pm 0.67^{\mathrm{g}}$ \\
\hline \multicolumn{6}{|l|}{ Commercial enzyme } \\
\hline Non protein $\mathrm{N}$ & $4.36 \pm 0.26^{\mathrm{h}}$ & $6.33 \pm 0.43^{g}$ & $7.38 \pm 0.27^{g f}$ & $8.27 \pm 0.10^{\mathrm{ef}}$ & $\begin{array}{l}9.51 \pm 0.49^{\mathrm{cd}} \\
90.49 \pm 0.49^{\mathrm{ef}}\end{array}$ \\
\hline Protein N & $95.64 \pm 0.26^{\mathrm{a}}$ & $93.67 \pm 0.43^{b}$ & $92.62 \pm 0.27^{\mathrm{cb}}$ & $91.73 \pm 0.10^{\mathrm{cd}}$ & $17.05 \pm 0.07^{\mathrm{cb}}$ \\
\hline Non casein $\mathrm{N}$ & $11.19 \pm 0.25^{\mathrm{g}}$ & $12.90 \pm 0.22^{\mathrm{f}}$ & $15.13 \pm 0.22^{\mathrm{e}}$ & $16.09 \pm 0.09^{\mathrm{d}}$ & $82.95 \pm 0.07^{\text {ef }}$ \\
\hline Casein N & $88.81 \pm 0.25^{\mathrm{a}}$ & $87.10 \pm 0.22^{b}$ & $84.87 \pm 0.22^{\mathrm{c}}$ & $83.91 \pm 0.09^{\mathrm{d}}$ & \\
\hline
\end{tabular}

Mean \pm SD of the same parameter within the same column with different superscript letters differ significantly ( $\mathrm{p}<0.05$ ). 
(a)

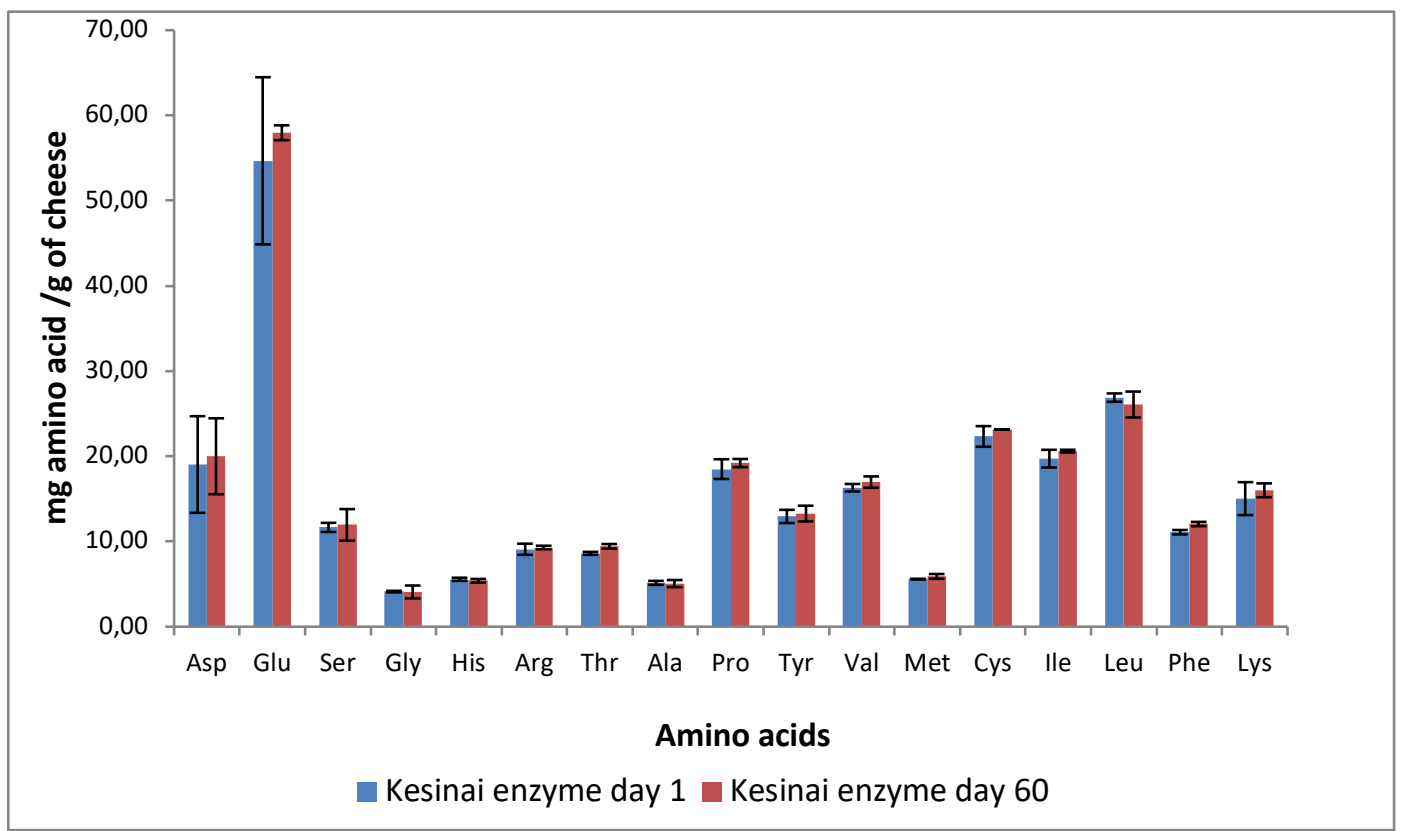

(b)



Fig 1. Level of Individual Free Amino Acid Detected in Cheese Made with Kesinai Enzyme (a) and Commercial Enzyme (b) 


\section{Individual Free Fatty Acid}

The present study shown that there were no $(p>0.05)$ differences were observed $\mathrm{C}_{18: 0}$ and $\mathrm{C}_{18: 1}$ value in cheese made with kesinai enzyme and commercial enzyme during ripening (Table III). But the relative percentage of fatty acids composition, $\mathrm{C}_{12: 0}, \mathrm{C}_{14: 0}$ and $\mathrm{C}_{16: 0}$ had shown moderate changes in both type cheeses. But, no differences were found in the fatty acids composition between cheeses made with the two coagulants. In cheese free fatty acid release as a result of lipolysis, especially short and medium chain fatty acid are directly contributing the cheese flavor. Long chain fatty acids $\left(\mathrm{C}_{12: 0}, \mathrm{C}_{14: 0}, \mathrm{C}_{16: 0}, \mathrm{C}_{18: 0}\right.$ and $\left.\mathrm{C}_{18: 1}\right)$ are considerably play only minor role in cheese flavour [46]. In this study, both cheeses were given long chain fatty acids composition during the ripening process. Hannon et al. [47] was also reported that long chain fatty acids are accumulated with ripening time in all types' cheeses. Furthermore, it was reported, cheddar cheese made with L.lactis, was producing significantly higher level of long chain fatty acids $\left(\mathrm{C}_{14: 0}\right.$, $\mathrm{C}_{16: 0}, \mathrm{C}_{18: 0}$ and $\mathrm{C}_{18: 1}$ ), this could be a lysis of the highly autolytic strain L.lactis [47].

\section{E. Texture Profile Analysis}

Table IV shows, the changes in texture profile parameter (hardness, adhesiveness, springiness, cohesiveness, gumminess and chewiness) during ripening experimental cheddar cheeses. Texture parameters tended to increase gradually during the early stage of ripening in both cheeses. The hardness of cheeses obtained with kesinai enzyme were $(\mathrm{P}<0.05)$ lower than those produced with commercial enzyme throughout the ripening period. It could be intense proteolytic activity in the breakdown of casein and first degradation products in cheese made with kesinai enzyme led to softer texture than those obtained with commercial enzyme [14]. The hardness was increased during four weeks of ripening and slows down gradually end of the ripening. Awad [27] reported that the increase in hardness during the first four weeks of ripening is correlated to loss of moisture which leads plasticiser in the protein matrix, as a result less elastic and more susceptible to fracture upon compression. Adhesiveness was no differences $(\mathrm{P}>0.05)$ among all aged cheeses whereas springiness and cohesiveness was gradually increased with ripening time in both types of cheese. The gumminess was lower $(p<0.05)$ in cheese made from kesinai enzyme than those made from commercial enzyme. During the early stage of ripening, gumminess was slightly increased and decreased gradually at end of the ripening in cheeses made with both types of coagulant. There is a correlation between cheese gumminess and hardness, the increased or decreased of cheese hardness were directly correlated with cheese gumminess [48]. Similarly, Chewiness was lower $(p<0.05)$ in cheese made with kesinai enzyme than those from commercial enzyme. It could be the higher proteolysis in cheese made by kesinai enzyme [27]. The chewiness was increased during early stage of ripening and decrease gradually end of the ripening in cheeses made with both types of coagulant. Chewiness was directly correlated with hardness as result cheeses become softer and smoother and hence, the chewiness values decreased at end of the ripening [49].

\section{F. Cheese Aroma (Volatile Compound) Profile}

The result was displayed by polar plots (Vaporprint ${ }^{\mathrm{TM}}$ ) using SAW detector frequency (Fig 2). This is obviously indicated, the cheeses were likely to have releasing more volatile compounds during ripening. Although the pattern of aroma compound found in cheeses made with kesinai enzyme and commercial enzyme were similar to each other with cheese ripening time. As monitored from polar plot display start at 0 and dial the clockwise direction until 20 seconds. Out of 20 (a-t) compounds only 7 were recorded as common compounds in both cheeses within the analysis time $(20 \mathrm{~s})$. However different cheese with ripening showed variation in the amount of every compounds [50]. This unique nature display might be the relative concentrations of the several volatile compounds making up the mix [50-51].

The signals of for the Cheddar cheeses with ripening time of $1,15,30,45$ and 60 days are summarized in a PCA score plot (Figure 3). The Principal Component 1 and Principal Component 2 factors resulted in a model that described 90 $\%$ of the total variance in the data. The ripened cheeses made with both coagulants were clearly separated with ripening period. Days 1, 15 and 30 of ripening were grouped each other in both cheeses and days 45 and 60 were appeared in same group. These results indicated that ripening stage was successfully monitored by electronic nose system based on the volatile components present in the cheese. The discrimination of ripened period is mainly due to changes of aroma components presence in cheese. Further, un-discrimination of 45 and 60 days ripened cheese samples were indeed a presence of very similar in term of volatile compounds [28].This result is a further confirmation of electronic nose suitability to differentiate the aroma components in cheese during ripening [28]-[52].

\section{CONCLUSIONS}

In the present study, moisture contents was higher in cheese made with kesinai enzyme than cheese made with commercial enzyme whereas protein contents and $\mathrm{pH}$ were lower in cheese made using kesinai enzyme compare to cheese made using commercial enzyme. In both cheese moisture contents declined with ripening period while $\mathrm{pH}$ was increased with ripening time. NPN and NCN found in cheese made with kesinai enzyme was higher than in cheese made with commercial enzyme. In both cheeses NPN and NCN were increased throughout the ripening period. Cheese made with commercial enzyme exhibited slightly higher level of free amino acids than cheese made with kesinai enzyme. Hardness, gumminess and chewiness increased in both types of cheese during early stage of ripening and decrease gradually at end of ripening. Such textual parameters were lower in cheese made with kesinai enzyme than cheese made from commercial enzyme. Moreover PCA analysis was performed to discriminate the cheeses with their ripening time. Discrimination was successfully achieved for day 1, 15, 30, and 45 and 60 days cheese samples obtained from both types of coagulant. 
TABLE III: FREE FATTY ACIDS (FFA) COMPOSITIONS (RELATIVE PERCENTAGE) IN CHEDDAR CHEESE MADE USING KESINAI ENZYME AND COMMERCIAL ENZYME.

\begin{tabular}{|c|c|c|c|c|c|}
\hline Type of coagulant & \multicolumn{5}{|c|}{ Ripening Days } \\
\hline \multicolumn{6}{|l|}{ Kesinai enzyme } \\
\hline & 1 & 15 & 30 & 45 & 60 \\
\hline \multicolumn{6}{|l|}{ C12:0 } \\
\hline & $12.88 \pm 0.09^{\mathrm{ab}}$ & $12.84 \pm 0.19^{\mathrm{ab}}$ & $12.08 \pm 0.76^{b}$ & $12.99 \pm 0.30^{\mathrm{ab}}$ & $13.88 \pm 0.32^{\mathrm{a}}$ \\
\hline \multicolumn{6}{|l|}{$\mathrm{C} 14: 0$} \\
\hline & $17.39 \pm 0.26^{\mathrm{b}}$ & $22.18 \pm 2.16^{\mathrm{a}}$ & $18.28 \pm 1.39^{\mathrm{b}}$ & $17.83 \pm 0.33^{b}$ & $18.25 \pm 0.02^{\mathrm{b}}$ \\
\hline \multicolumn{6}{|l|}{$\mathrm{C} 16: 0$} \\
\hline \multicolumn{6}{|l|}{ C18:0 } \\
\hline \multirow{2}{*}{ C18:1 } & $11.25 \pm 0.23^{\mathrm{ab}}$ & $10.95 \pm 0.47^{\mathrm{b}}$ & $10.82 \pm 0.77^{b}$ & $10.64 \pm 0.36^{\mathrm{b}}$ & $10.79 \pm 0.59^{b}$ \\
\hline & $25.75 \pm 1.74^{\mathrm{a}}$ & $26.16 \pm 0.03^{\mathrm{a}}$ & $26.67 \pm 0.60^{\mathrm{a}}$ & $26.93 \pm 1.82^{\mathrm{a}}$ & $25.98 \pm 0.61^{\mathrm{a}}$ \\
\hline \multicolumn{6}{|l|}{ Commercial enzyme } \\
\hline C12:0 & $12.73 \pm 0.03^{\mathrm{ab}}$ & $13.24 \pm 0.44^{\mathrm{a}}$ & $12.0 \pm 0.90^{\mathrm{b}}$ & $13.66 \pm 0.24^{\mathrm{a}}$ & $13.14 \pm 0.05^{\mathrm{a}}$ \\
\hline $\mathrm{C} 14: 0$ & $18.00 \pm 1.02^{\mathrm{b}}$ & $21.39 \pm 0.44^{\mathrm{a}}$ & $16.94 \pm 0.05^{\mathrm{b}}$ & $17.79 \pm 0.93^{b}$ & $17.34 \pm 0.35^{b}$ \\
\hline C16:0 & $31.94 \pm 0.16^{\mathrm{ab}}$ & $29.65 \pm 1.10^{\mathrm{bc}}$ & $34.37 \pm 3.14^{\mathrm{a}}$ & $31.56 \pm 0.51^{\mathrm{ab}}$ & $32.30 \pm 0.23^{\mathrm{ab}}$ \\
\hline C18:0 & $12.80 \pm 0.24^{\mathrm{a}}$ & $10.20 \pm 1.77^{b}$ & $11.59 \pm 0.40^{\mathrm{ab}}$ & $11.07 \pm 0.22^{b}$ & $10.84 \pm 0.25^{\mathrm{b}}$ \\
\hline C18:1 & $24.53 \pm 0.63^{\mathrm{a}}$ & $25.52 \pm 2.69^{\mathrm{a}}$ & $25.08 \pm 2.66^{\mathrm{a}}$ & $25.92 \pm 0.98^{\mathrm{a}}$ & $26.38 \pm 0.29^{\mathrm{a}}$ \\
\hline
\end{tabular}

Mean \pm SD of the same parameter within the same column with different superscript letters differ significantly $(\mathrm{p}<0.05)$.

TABLE IV: TEXTURE PROFILE CHEDDAR CHEESE MADE USING KESINAI ENZYME AND COMMERCIAL ENZYME.

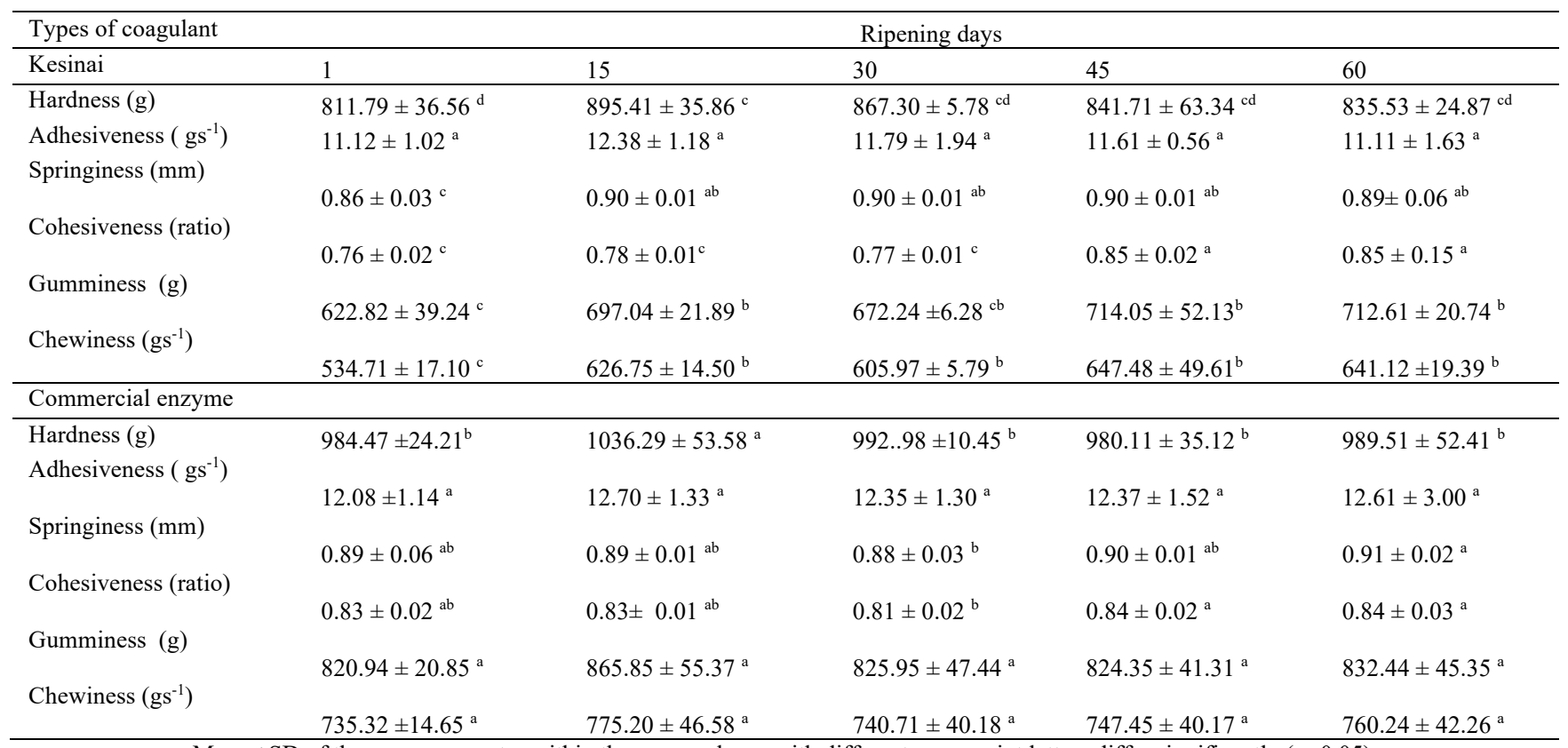




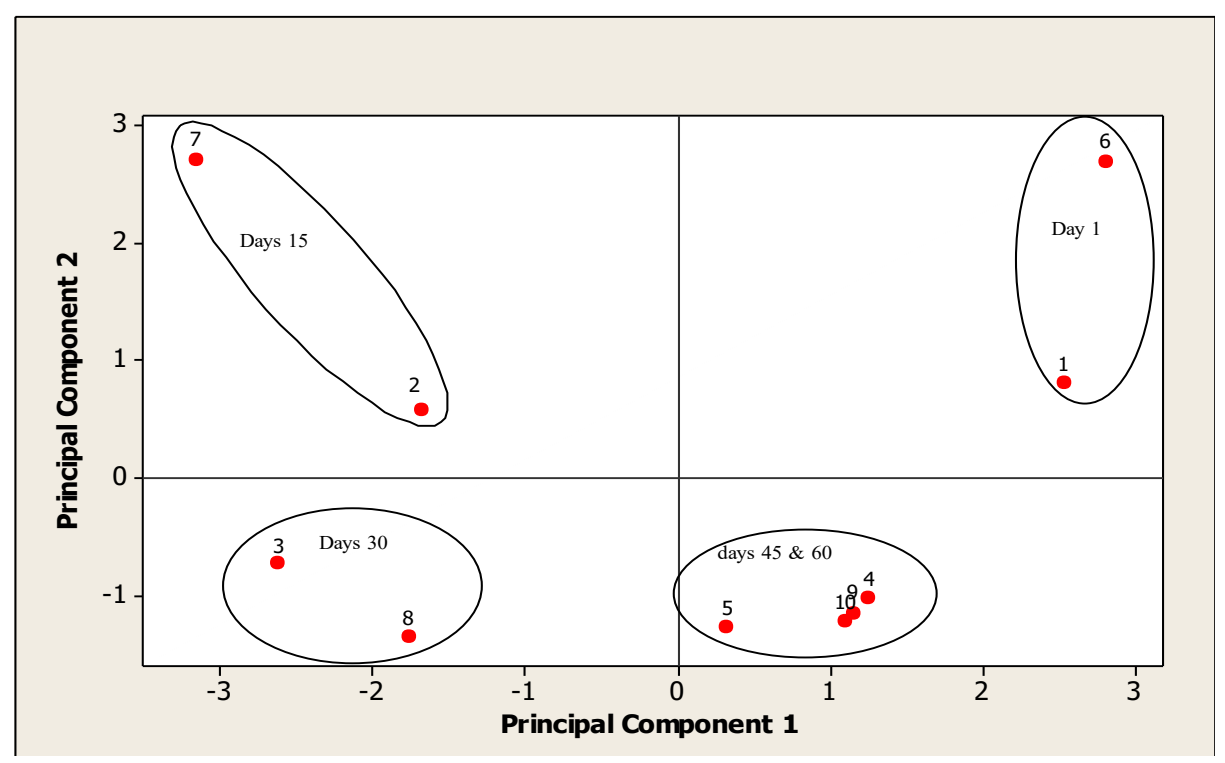

Fig 2. Score Plot Obtained by "Z" Nose Data for Cheddar Cheeses at Different Ripening Age Categories. Cheese Made from Kesinai Enzyme (1-5) and Commercial Enzyme (6-10).

\section{ACKNOWLEDGMENT}

The author is grateful to eastern university, Sri Lanka, Sri Lanka and Universiti Putra Malaysia, Malaysia for financial assistant to the research work.

\section{REFERENCES}

[1] Antao, C.M, and Malcata, F.X. Plant serine proteases: biochemical, physiological and molecular features. Plant Physiological Biochemistry, vol. 43, pp. 637-650, 2005

[2] Tavaria, F. K, Sousa, M. J, Domingos, A, Malcata, F. X, Brodelius, A, Clemente, A, and Pais, M. S. Degradation of caseins from different milk types by extracts of Centaurea calcitrapa. Journal of Agricultural and Food Chemistry, pp. 45, pp, 3760-3765, 1997.

[3] Bruno, M. A, Lazza, M. C, Errasti, M. E, Lò pez, L.M.I, Caffini, N. $\mathrm{O}$, and. Pardo, M. F. Milk clotting and proteolytic activity of an enzyme preparation from Bromelia hieronymi fruits. LWT - Food Science and Technology, vol. 43, no. 4, pp. 695-701, 2010.

[4] Merheb-Dini, C, Gomes, E, Boscolo, M, and da Silva, R. "Production and characterization of a milk-clotting protease in the crude enzymatic extract from the newly isolated Thermomucor indicaeseudaticae N31:(Milk-clotting protease from the newly isolated Thermomucor indicae-seudaticae N31)." Food Chemistry, vol 120, no. 1, pp. 87-93, 2010.

[5] Rogelj, I., Perko, B, Francky, A, Penca,V, and Pungerčar, J. Recombinant lamb chymosin as an alternative coagulating enzyme in cheese production. Journal Dairy Science, vol. 84, pp. 1020-1026, 2001.

[6] Roseiro, L.b, Barbosa, M, Ames, J.M, and Wilbey, R. A. Cheese making with vegetable coagulants - The use of Cynara L . for the production of ovine milk cheese. International Journal of Dairy Technology, vol. 56, pop. 76-85, 2003.

[7] Chazarra, S, Sidrach, L, López-Molina, D, and Rodríguez-López, J. N. Characterization of the milk-clotting properties of extracts from artichoke (Cynara scolymus, L.) flowers. International Dairy Journal, vol. 17 , pp. 1393-1400, 2007.

[8] Silva,S. V, and Malcata, F. X. Studies pertaining to coagulant and proteolytic activities ofplant proteases from Cynara cardunculus. Food Chemistry, vol.89, pp. 19-26. 2005.

[9] Idris, Y.M.A, Sipat, A.B, Shuhaimi, M, and Yazd, A.M. Inhibition of enzymatic browning during the extraction of a milk coagulation protease from Streblus asper (Kesinai). Pakistan Journal of Biology Sciences, vol. 2, pp 378-381, 1999.

[10] Yazid, A.M, Fong, H.M, Sipat, A.B, Shuhaimi,M, and Idris, Y.M. A. Proteolysis of milk and Casein fraction by Streblus asper (Kasinai) Extract. Pakistan Journal of Biological Science, vol. 2, no. 3, pp. 654-659, 1999.

[11] Senthilkumar, S, Ramasamy, D, and Subramanian, S. Isolation and partial characterisation of milk-clotting aspartic protease from Streblus asper. Food Science and Technology International, vol. 12, pp. $103-109,2006$.

[12] Idris, Y.M.A. Kesinai ( Streblus asper) protease as a potential milk coagulation enzyme. PhD Thesis. University Putra Malaysia, 2000.

[13] Mohamed Ahmed, I. A, Morishima, I, Babiker, E. E, and Mori, N. Characterization of partially purified milk-clotting enzyme from Solanum dubium Fresen seeds. Food Chemistry, vol. 116, pp. 395400, 2009.

[14] Galán, E, Prados, F, Pino, A, Tejada, L, and Fernández-Salguero, $\mathrm{J}$. Influence of different amounts of vegetable coagulant from cardoon Cynara cardunculus and calf rennet on the proteolysis and sensory characteristics of cheeses made with sheep milk. International Dairy Journal, vol. 18, pp. 93-98, 2008.

[15] Fox, P. F, Guinee, T. P, Cogan, T.M, and Mc Sweeney, P.L.H Fundamental of Cheese Science. Gaithesburg, Mayyland, An Aspen Publisher, Inc, 2000.

[16] Punidadas, P, Tung, M. A, and Feirtag, J. Potential use of homogenized whey protein dispersions and process modification for the manufacture of low fat and reduced fat cheddar type cheeses. International Journal of Dairy Technology, vol. 53, pp. 45-50, (2000).

[17] AOAC. Official methods of analysis (15th ed., Vol. 2). Arlington, VA, USA: Association of Official Analytical Chemists, 1990.

[18] Barbano, D. M, and J. M. Lynch. Crude and protein nitrogen bases for protein measurement and their impact on current testing accuracy. Journal of Dairy Science vol. 75, pp. 3210-3217, 1992.

[19] Carmona, M. A, Sanjuán, Gómez, R, and Fernández-Salguero, J. Effect of starter cultures on the physico-chemical and biochemical features in ewe cheese made with extracts from flowers of Cynara cardunculus L. Journal of the Science of Food and Agriculture, vol.79, pp. 737-744, 1999 .

[20] Patel, H. G., Upadhyay, K. G., Miyani, R. V. and Pandya, A. J. (1993). Instron texture profile of buffalo milk Cheddar cheese as influenced by composition and ripening changes. Food Quality and Preference 4: 187-192.

[21] Khan, J. K, Kuo, Y. H, Kebede, N, and Lambein, F. Determination of nonprotein amino acids and toxins in Lathyrus by high performance liquid chromatography with precolumn phenylisothiocyanate derivatization. Journal of Chromatogrphy. A, vol. 687, pp 113-119, 1994. 
[22] Rozan, P, Kuo, Y. H, and Lambein, F. Free Amino acids present in commercially available seedlings sold for human consumption. A potential hazard for consumers. Journal of Agriculture Food and Chemistry, vol. 48, pp. 716-723, 2000.

[23] Alewijn, M. Sliwinski, E.L, and Wouters, J.T.M. Production of fatderived (flavour) compounds during the ripening of Gouda cheese. International Dairy Journal, vol. 15, pp. 733-740, 2005.

[24] Alewijn, M, Sliwinski, E.L, and Wouters, J.T.M. A fast and simple method for quantitative determination of fat-derived medium and low-volatile compounds in cheese. International Dairy Journal, vol.13, pp. 733-741, 2003,

[25] Cocks, L.V. and Van Rede, C. (1966). Laboratory hand book for oil and fats analysts. Academic Press.

[26] Awad, S. Hassan, A. N, and Muthukumarappan, K. Application of exopolysaccharide-producing cultures in reduced- fat cheddar cheese: Texture and melting properties. Journal of Dairy Science, vol. 88, pp. 4204-4213, 2005.

[27] Awad, S. Texture and flavour development in Ras cheese made from raw and pasteurized milk. Food chemistry, vol. 97, pp, 394-400, 2006.

[28] Gursoy, O, Somervuo, P, and Alatossava, T. Preliminary study of ion mobility based electronic nose MGD-1 for discrimination of hard cheeses. Journal of Food Engineering, vol. 92, pp. 202-207, 2009.

[29] Manaf, Y. N A, Osman, A., Lai, O.M, Long, K, and Ghazali, H.M. Characterisation of musk lime (Citrus microcarpa) seed oil. Journal of the Science of Food and Agriculture, vol. 88, pp. 676-683, 2008.

[30] Pino, A, Prados, F, Galán, E, McSweeney, P.L.H, and FernándezSalguero, J. Proteolysis during the ripening of goats' milk cheese made with plant coagulant or calf rennet. Food Research International, vol. 42, pp. 324-330, 2009.

[31] Hofi, A. A, Youssef, E. H, Ghoneim, M. A, and Tawab, G. A. Ripening changes in Cephalotyre "Ras" cheese manufactured from raw and pasteurised milk with special reference to flavour. Journal of Dairy Science, vol. 53, no. 9, pp. 1207-1212, 1970.

[32] McSweeney, P. H, and Fox, P. F. Methods of chemical analysis. In P. F. Fox (Ed.), Cheese, chemistry, physics and microbiology (Vol. 1, 2nd ed., pp. 389-438). London: Chapman and Hall, 1993

[33] Aryana, K, and Zhaque, Z. Texture and microflora of vallagret cheese during maturation. International Journal of Dairy Technology, vol. 58 no.1, pp. 47-50, 2005

[34] Sousa, M. J, and Malcata, F. X. Comparison of plant and animal rennets in terms of microbiological, chemical and proteolysis characteristics of ovine cheese. Journal of Agriculture and Food Chemistry, vol. 45, pp. 74-81, 1997.

[35] Fernández-Salguero, J, Prados, F, Calisto, F, Vioque, M, Sampaio, P and Tejada, L. Use of recombinant cyprosin in the manufacture of ewe's milk cheese. Journal of Agricultural and Food Chemistry, vol. 51, pp. 7426-7430, 2003

[36] Heimgartner, U, Pietrazak, M, Greetsen, R, Brodelius, P, Figueredo, M, Figueiredo, A.C, and Pais, S.S.M. Purification and partial characterization of milk clotting protease's from flowers of Cynara cardunculus. Phytochemistry, vol. 29, pp. 1405-1410,1990.

[37] Tejada, L, Abellán, A, Cayuela, J.M, Martí nez-Cacha, A, and Fernández-Salguero, J. Proteolysis in goats' milk cheese made with calf rennet and plant coagulant. International Dairy Journal, vol.18, pp. 139-146, 2008

[38] Lane, C. N, and Fox, P. F. Contribution of starter and adjunct lactobacilli to proteolysis in Cheddar cheese during ripening. International Dairy Journal , vol. 6, pp. 715-728, 1996.

[39] El-Soda, M, Madkor, S. A, and Tong, P. S. Adjuncts cultures: recen developments and potential significance to cheese industry. A review. Journal of Dairy Science, vol. 83, pp. 609-619, 2000

[40] Chapot-Chartier, M. P, Deniel, C, Rousseau, M, Vassal, L, and Gripon, J. C. Autolysis of two strains of Lactococcus lactis during cheese ripening. International Dairy Journal, vol.4, pp. 251-269, 1994.

[41] Kawabata, S, Vassal, L, Le Bars, D, Cesselin, B, Nardi, M, and Gripon, J. C. Phage-induced lysis of Lactococcus lactis during SaintPaulin cheese ripening and its impact on proteolysis. Lait, vol. 77, pp. 229-239, 1997.

[42] Morgan, S, Ross, R. P, and Hill, C. Increasing starter cell lysis in Cheddar cheese using bacteriocin-producing adjunct. Journal of Dairy Science, vol. 80, pp. 1-10, 1997

[43] Ardö, Y, Thage, B. V, and Madsen, J. S. Dynamics of free amino acid composition in cheese ripening. Australian Journal of Dairy Technology, vol.57, pp. 109-115, 2002.
[44] Fox, P. F. Proteolysis during cheese manufacture and ripening. Journal of Dairy Science, vol. 72, pp. 1379-1400, 1989.

[45] Crow, V. L., Coolbear, T, Holland, T, Pritchard, G. G, and Martley, F. G. Starters as finishers: Starter properties relevant to cheese ripening. International Dairy Journal, vol 3, no 4-6,pp. 423-460,1993.

[46] Molimard, P, and Spinnler, H. E. Review: Compounds involved in the flavour of surface mould-ripened cheeses: Origins and properties. Journal of Dairy Science, vol. 79, pp. 169-184, 1996.

[47] Hannon, J.A, Kilcawley, K.N, Wilkinson, M.G, Delahunty, C.M, and Beresford, T.P. Flavour precursor development in Cheddar cheese due to lactococcal starters and the presence and lysis of Lactobacillus helveticus. International Dairy Journal, vol. 17, 316327, 2007.

[48] Beal, P, and Mittal, G.S. Vibration and compression responses of Cheddar cheese at different fat content and age. Milchwissenschaft, vol. 55, pp. 139-142, 2000

[49] Kanawjia, S. K, Rajesh, P, Sabikhi, L, and Singh, S. Flavour, chemical and textural profile changes in accelerated ripened Gouda Cheese. Lebensm.-Wiss. u.-Technology, vol. 28, pp. 577-583, 1995.

[50] Staples, Edward J, and Shekar Viswanathan. "Development of novel electronic nose as an environmental tool." Air \& Waste Management Association, St. Louis, MO, 1999.

[51] Gan, H.L, CheMan, Y.B, Tan, C.P., NorAini, I, and Nazimah, S.A.H. Characterization of vegetable oils by surface acoustic wave sensing electronic nose. Food Chemistry, vol. 89, pp, 507-518, 2004.

[52] Benedetti, S, Sinelli, N, Buretti, S, and Riva, M. Shelf life of Crescenza cheese as measured by electronic nose. Journal of Dairy Science, vol 88, pp.3044-3051, 2005

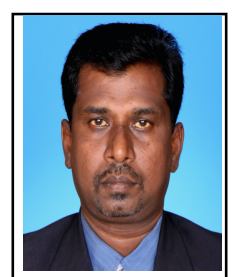

Dr. Mylvaganam Pagthinathan a Senior Lecturer in Department of Animal Science, Faculty of Agriculture, Eastern University, Sri Lanka. Dr. Mylvaganam Pagthinathan was basically graduate from Bachelor of Veterinary Science and animal Science and did the PhD in Dairy Technology in Malaysia. He is engaged in teaching and research work in the same department and has published national and international journals, he is supervising undergraduate and postgraduate students in the field of Dairy technology and Animal reproductive physiology. (Email address: pagthinathanm@esn.ac.lk). 